\title{
Foreign Direct Investments In Bangladesh: Some Recent Trends And Implications
}

Sonia H. Manzoor, Westminster College, USA

Manzoor E. Chowdhury, Lincoln University, USA

\begin{abstract}
For many developing nations, Foreign Direct Investment (FDI) has been viewed as a powerful instrument for economic development. In particular, FDI has become a major source of capital formation and an instrument for facilitating knowledge transfer. Expansion of FDI has led countries to build physical capital, increase employment, trade, and gross domestic product, and consequently helped to eradicate poverty. Using secondary data for Bangladesh, this paper investigates the effect of FDI on some major economic indicators of growth and examines the functional relationship between FDI and indicators.
\end{abstract}

Keywords: Foreign Direct Investments; Bangladesh; Kuznet's Curve; Growth

\section{INTRODUCTION}

¿ mmediately after Bangladesh's liberation in 1971, all industries were nationalized. From 1972-78, these industries performed inefficiently and incurred losses. This created tremendous political pressure, and the government took a more market-economy approach and was forced to slowly privatize the nationalized industries during1979-85. Prior to1980, like other developing countries, Bangladesh was doubtful about the intentions of Foreign Direct Investments (FDI), and many restrictions were imposed to discourage FDI inflows. However, lack of domestic financial ability and low economic growth ultimately forced Bangladesh to follow the footsteps of other developing countries and take policies to encourage FDI inflows into the country. FDI was perceived as a powerful instrument for economic development, growth, and employment. It became a source of capital and an instrument for facilitating knowledge transfer.

To overcome the deficiency in the domestic financial capacity, Bangladesh adopted the Foreign Private Investment Act in 1980 to encourage FDI. This Act provided protection to foreign investors against expropriation and further ensured full repatriation of profits and capital. In addition, it ensured equal treatment for local and foreign investors, and allowed 5-7 years of corporation tax holiday to foreign industries. ${ }^{1}$ The intention behind FDI liberalization was to encourage economic growth, increase employment, and create a new source for much needed capital.

The purpose of our paper is to provide a brief overview of the FDI trends in Bangladesh and to investigate the impact of FDI inflows on major economic variables (GDP, total capital formation, Exports and Imports) using data from the World Bank, UNCTAD and Bangladesh Bank Statistics. The impact of FDI on economic growth variables has been investigated in earlier studies for the case of Bangladesh (Hossain (2009), Adhikary (2011), Rahman (2012), Faruq (2013), and Islam (2014)). These earlier studies, however, postulated a linear relationship between FDI and the economic growth variables. Our paper improves upon previous research by investigating the functional relationships between FDI and important economic variables instead of imposing a linear relationship. The investigation of searching for a more relevant functional relationship originates from Kuznet's (1955) inverted-U hypothesis. Kuznet's inverted-U theory suggests that as income per capita increases, inequality will increase in the early stages, then reach a maximum and then decline as income per capita reaches a high level. This relationship between per capita income and inequality is known as the inverted-U relationship or the Kuznet's Curve. Later many studies have extended the functional relationship investigation to the environmental sector (such as, Cole

1 A detailed discussion of the Foreign Private Act of 1980 can be found in "Guide to Investment in Bangladesh Foreign Private Investment (Promotion and Protection) Act, 1980: http://bdlaws.minlaw.gov.bd/print_sections_all.php?id=597 
(2004), Richmond and Kaufmann (2006), and Luzzati and Orsini (2009)). Their findings have varied from an inverted-U to a linear monotonous relationship. Our paper extends this literature in the environmental sector and examines the appropriate functional relationship between FDI and the economic variables for the case of Bangladesh.

\section{LITERATURE}

Economic impact of FDI on the growth of Bangladesh economy dates back to as early as 1984 soon after the 1980 Foreign Private Investment Act. Rothgeb (1984) investigates the impact of FDI flows to Bangladesh on the growth of the country and he finds a positive impact. In recent years, Quader (2009) analyzes catalyst variables of FDI inflows for Bangladesh using data from 1990-91 to 2005-06, and finds positive results for wages, trade openness, net export, GDP growth and tax rate. Hossain (2009) finds a high positive correlation between FDI inflows and exports and imports for Bangladesh. Adhikary (2011) investigated amongst other variables the linkage between FDI and economic growth for Bangladesh for the period 1986 to 2008 and found a strong relationship between the two variables. More recent studies by Omar Faruq (2013), Rahman (2012) and Islam (2014) also found positive correlation between FDI and GDP. In addition to GDP, Rahman (2012) and Islam (2014) further investigates impact of FDI on domestic investments and exports and find positive linear relationship.

Though negative impact of FDI on economic growth has not been observed for the case of Bangladesh, some studies reveal negative or no significant impact for other countries. Ali, Rikunujjaman and Alam (2015) using time series data between 1973 and 2013 for the case of Bangladesh found their results did not support a robust link between FDI and GDP in Bangladesh. Azam (2010) investigates the impact of FDI on economic growth during 1980-2009 for Bangladesh, India, Pakistan and Sri Lanka. His study finds positive significant impacts for Bangladesh and Pakistan, insignificant but positive impact for the case of India, and surprisingly significant but negative impact for the case of Sri Lanka. For the case of Pakistan, Saqib, Masnoon and Rafique (2013) find that the country's GDP is negatively impacted by foreign investments. Lee, et. al. (2009) investigated the relationship between FDI inflows, exchange rate, and economic growth of Kazakhstan using weighted least squares estimates and their results show minimum significant impact of FDI on GDP growth of the country. The negative relationship comes from the dependency theories, which argues that in the long-run large foreign players may have a negative impact on the growth and development of the host country's domestic firms, because of their large capital capacities, superior technologies, greater market access and better managerial skills (Marksun \& Venables (1997), Agosin \& Mayer (2000), Kumar \& Pradhan (2002)). In addition, the dependency theories argue that FDI may have a negative impact on income distribution, employment, national sovereignty and autonomy of a country (Musila and Sigue, 2006).

\section{FUNCTIONAL RELATIONSHIP BETWEEN FDI AND ECONOMIC GROWTH VARIABLES}

The economic impact of FDI has been investigated by many for various countries. Some results as discussed above have found positive impacts, while others have shown negative impacts of FDI on economic growth variables. This earlier research along with the dependency theory suggests a monotonous linear relationship may not be always appropriate. For the case of Bangladesh, Hossain (2009) found FDI to have a positive impact on the balance of payment of Bangladesh. Rahman (2012), Faruq (2013), and Islam (2014) find positive correlation between FDI and GDP. In addition to GDP, Rahman (2012) further investigates impact of FDI on domestic investments and exports, however, these previous research considers FDI as the only independent variable. Our study contributes to this literature by not limiting the research to a linear relationship, but rather allowing other functional forms, to investigate the complex relationship between FDI and the economic variables. Furthermore, our research also looks at the Kuznet's relationship, which to the best of our knowledge has not been investigated previously. Finally, our research considers other independent variables along with FDI (not considered by Rahman (2009), Faruq (2013) and Islam (2014)) to investigate the impact on the growth variables.

Three types of relationships can be expected from the FDI and the economic variables: Kuznet's inverted-U, linear monotonous and $\mathrm{N}$-shaped curve. 
Figure 1. Relationships between FDI and the economic variable.

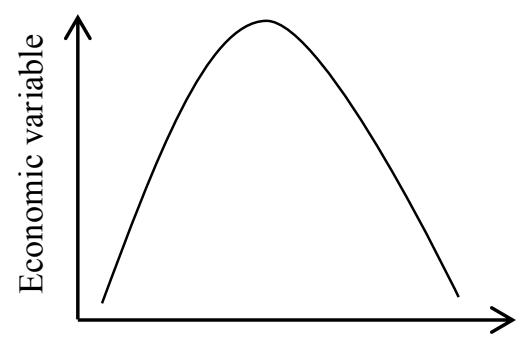

Inverted-U relationship

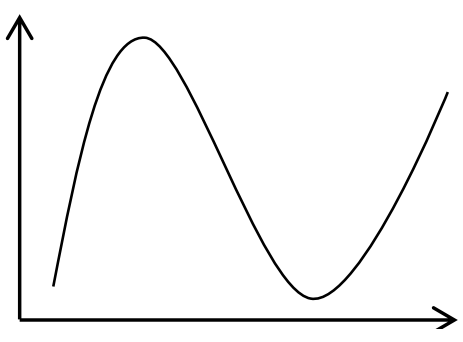

FDI

$\mathrm{N}$-shaped curve

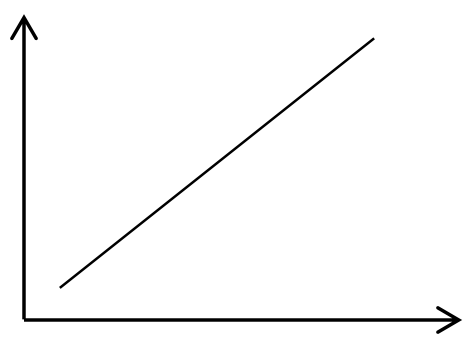

Linear Monotonous relationship

The Kuznet's inverted U relationship suggests that as FDI increases, the dependent economic variables (GDP, Exports, Imports and others) increase in the early stages, then reach a maximum and then declines as FDI reaches a high level. The linear monotonous relationship which had been investigated in the previous studies, suggests an increase in FDI will increase the economic variable (some studies as mentioned in literature review have found a negative relationship which would be a monotonously decreasing function). The N-curve suggests that FDI and economic variables have a positive relationship only at lower level and higher level of FDI but not in the moderate range. For the case of Bangladesh, earlier research has investigated only the linear relationship between FDI and economic growth. The Kuznet's and the N-shaped relationships have not been investigated in these previous studies.

\section{FDI Inflows to Bangladesh}

In 1980, to encourage FDI inflows, Bangladesh adopted the Foreign Private Investment Act. The intention behind the act, as mentioned earlier, was mainly to generate a new source of capital source for the country. Figure 2 below shows that despite the fluctuations in the flow of FDI inflows into Bangladesh there has been a general upward trend in the inflow since 1994. The figure demonstrates that FDI inflow into Bangladesh has increased sharply from 1995 to 2014. One of the factors contributing to this tremendous increase has been the exploratory investment of many corporations into the nation's natural gas reserves. The capacity of the reserves was estimated to be greater than 10 trillion cubic feet by the U.S. Geographical Survey (UNCTAD report 2000). Provided with such capacity, the Bangladesh government finally liberalized the energy sector to attract more FDI. Along with the energy sector liberalization, the government also eased capital controls by decreasing bureaucracy to allow private firms to undertake foreign loans without government permission. 
Figure 2. FDI inflows to Bangladesh

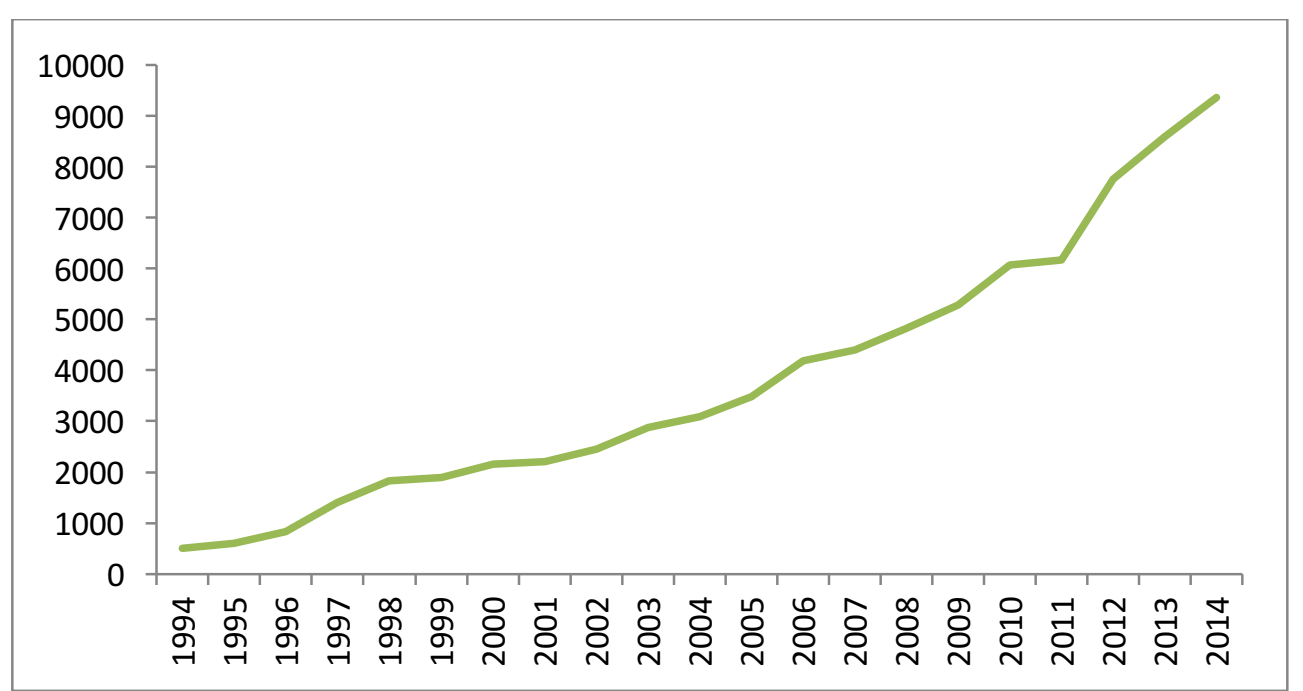

Data Source: UNCTAD STAT, FDI inflows measured in millions of US dollars at current prices and exchange rates

Despite major growth in FDI inflow into Bangladesh since 1994 Figure 3 shows that the average FDI inflow has remained below $6 \%$ of GDP during the period of our study. Factors that are working as a hindrance to FDI inflow are lack of infrastructure, government bureaucracy, corruption, and most importantly political unrest.

Figure 3. FDI inflows as a percentage of GDP

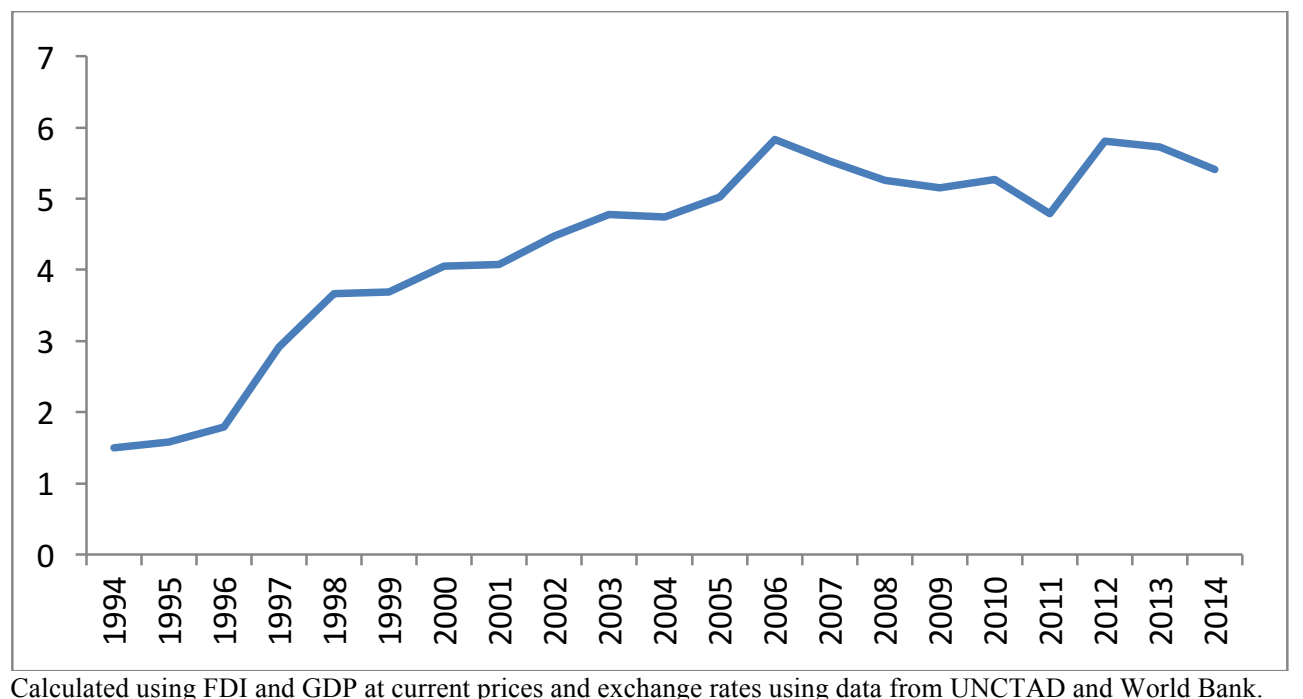

\section{Sectoral Comparison}

Instead of the overall FDI, the sectoral comparison provides some interesting findings. In 1995 Bangladesh government opened-up mobile telecommunications sector to attract joint ventures and millions of dollars in FDI in this sector. Figure 4 below provides an overview of the FDI inflows into the major sectors of the economy from 1996-2014. The graph clearly exhibits a dominance of FDI inflow in the telecommunication sector during the years 2005-2008. This is mainly because of the absence of ground telephone infrastructure in Bangladesh where the 
mobile service provided an attractive alternative. Besides Norway's Telenor, the other large investors in telecommunications have been Orascom from Egypt, Warid from UAE and Sing Tel from Singapore. However, total FDI inflow to Bangladesh dropped by approximately 34\% between 2008 and 2009. According to UNCTAD's World Investment Report 2010 this drop can be explained by a 60\% decrease in telecom sector during that time period. The uncertainty surrounding the renewal of mobile operator licenses (which were to expire in 2011) contributed to this downturn. Investments in this sector never returned to the 2008 level of \$641.4 million.

Figure 4. Sectoral FDI inflow (in millions of \$)

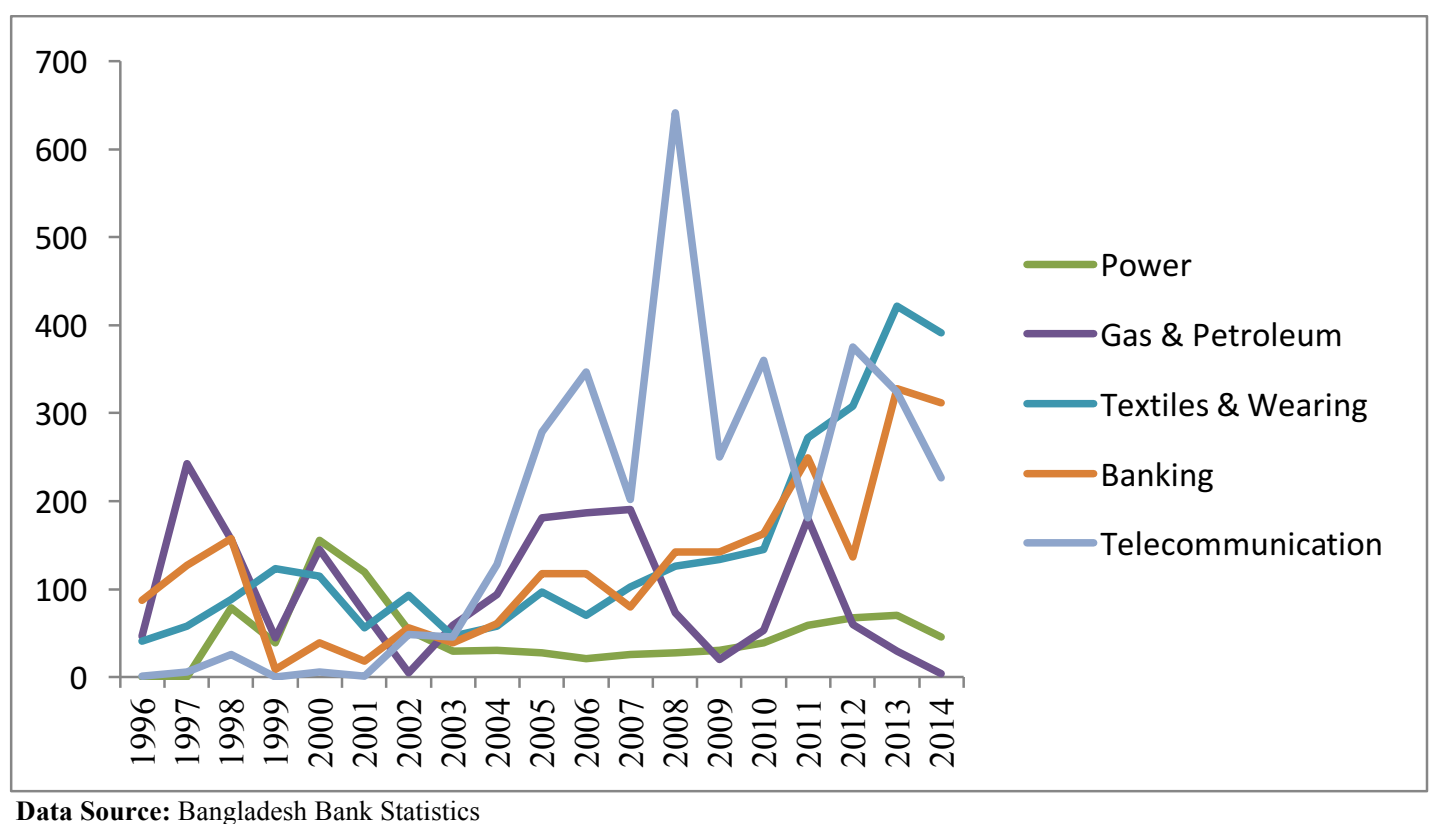

Figure 4 illustrates that the capital inflow into gas and petroleum was the highest in 1998 ( $\$ 230.4$ million) and then started to decline except for one or two years. The decline was more significant since 2005 because of recent blowouts in the gas fields that have led to lawsuits by the country against foreign corporations. The estimate for the loss of gas in the blowouts has varied from 300 - 500 billion cubic feet (Mahmud (2014), and Khan and Nasir (2014)); an amount estimated to be worth more than two years of power generation for the country. Other sectors that deserve mention are the banking and the textile industry. Foreign investors have been investing in the Banking sector since the1990s when Bangladesh started to adopt various financial liberalization policies. The Textile and Wearing industry like the Banking industry has also been growing and attracting significant FDI because of gradually improving labor standards and relatively lower wages.

Analysis of inflow of FDI into sectors indicates that there have been major shifts in the sectors. During the 90s Gas and Petroleum and Telecom attracted the major proportion FDI inflow into the country. Investigation of FDI inflow clearly shows that Gas and Petroleum sector FDI inflow has declined tremendously and the Telecom sector is showing recent decline as well. In the last five years, FDI flow to the Banking and Textile sectors has been growing.

Figures5 and 6 highlights the shift in recent years towards the service sectors. This shift is attributed to the country's agreement in 1995 with the World Trade Organization to liberalize the service sectors like power and energy, banking, insurance and telecommunications. One notable surprise is the lack of FDI into the power sector despite the dire need of power supply in the country. This is perhaps due to the political resistance of the public to hand over power supply to foreign companies. 
Figure 5. Sectoral Distribution of FDI

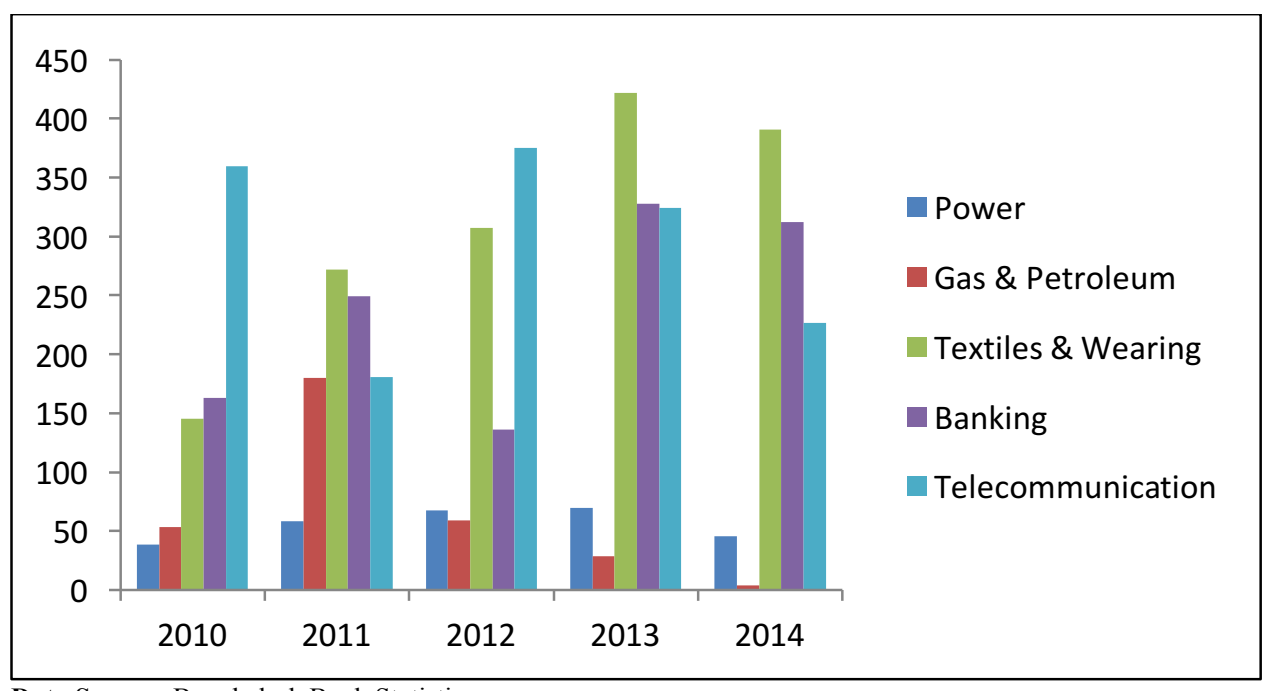

Data Source: Bangladesh Bank Statistics

Figure 6. FDI Inflow into Top Three Sectors (In millions of dollars)

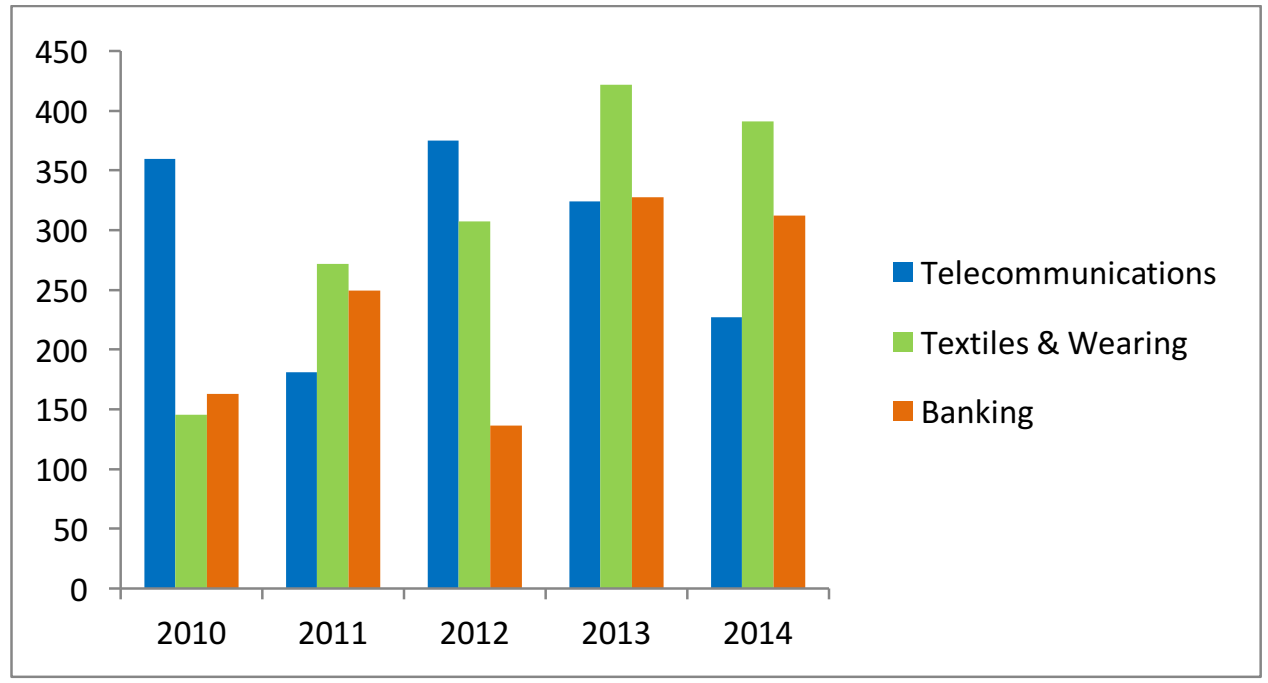

Data Source: Bangladesh Bank Statistics

Table 1 below shows net FDI inflows to Bangladesh from major investing countries from 2010-2014 in ascending order. The table shows the changes in the ranking of top investing countries because of the shifts in investment sectors as well as changes in equity stakes of foreign companies investing in Bangladesh. Another major change since 2010 has been that the foreign telecommunications investors like Orascom (from Egypt) and Telenor (from Norway) have recently raised $\$ 102 \mathrm{~m}$ and $\$ 143 \mathrm{~m}$ from corporate bonds and public offerings, respectively. These deals clearly indicate a healthy local market as a source of financing in Bangladesh. The $\$ 143 \mathrm{~m}$ by Telenor known as Grameen Phone in Bangladesh raised a total \$143 million from IPOs sold in the local market, of which \$71m was from local retail investors and $\$ 70 \mathrm{~m}$ is from local institutions. 
Table 1. Net FDI Inflows from Top 10 Countries (in millions of \$)

\begin{tabular}{|c|c|c|c|c|c|c|c|c|c|}
\hline Country & 2010 & Country & 2011 & Country & 2012 & Country & 2013 & Country & 2014 \\
\hline Singapore & 317.2 & Egypt & 152.3 & Malaysia & 247.4 & U.K. & 191.4 & U.K. & 181.0 \\
\hline Germany & 109.1 & Germany & 133.9 & U.K. & 136.9 & Singapore & 162.4 & South Korea & 134.7 \\
\hline U.K & 105.7 & U.S.A. & 117.7 & Egypt & 126.6 & Malaysia & 123.0 & Pakistan & 130.7 \\
\hline Netherlands & 64.9 & U.K. & 116.3 & South Korea & 97.6 & Netherlands & 116.6 & Singapore & 117.1 \\
\hline Hong Kong & 63.8 & South Korea & 113.1 & Netherlands & 79.8 & South Korea & 111.0 & Hong Kong & 111.4 \\
\hline U.S.A. & 57.0 & Hong Kong & 104.8 & Hong Kong & 54.1 & Egypt & 94.4 & Norway & 103.6 \\
\hline India & 43.2 & Australia & 72.8 & Switzerland & 44.7 & Japan & 94.4 & Japan & 95.7 \\
\hline South Korea & 40.0 & Pakistan & 70.5 & $\begin{array}{l}\text { British Virgin } \\
\text { Islands }\end{array}$ & 43.9 & Hong Kong & 81.4 & Netherlands & 78.7 \\
\hline Norway & 39.2 & Japan & 46.6 & U.S.A. & 43.8 & U.S.A. & 76.0 & India & 67.8 \\
\hline UAE & 24.5 & SriLanka & 31.6 & Australia & 39.8 & $\begin{array}{l}\text { British Virgin } \\
\text { Islands }\end{array}$ & 52.8 & SriLanka & 61.4 \\
\hline
\end{tabular}

Data Source: Bangladesh Bank Statistics

Table 2 below shows the sectors receiving the highest percentage of investments for 2014 from the top ten countries. For Japan the interesting observation is that $87.6 \%$ of its investments were not in the major sectors. $14.35 \%$ of Japan's investment was in Fertilizer and $60.4 \%$ of its investments were not specified by Bangladesh Bank since these did not belong to any major FDI segment.

Table 2. Net FDI inflows from top 10 Countries by sectors for 2014 (in millions of $\$$ )

\begin{tabular}{|c|c|c|c|c|c|c|c|c|c|c|}
\hline Sector & UK & $\begin{array}{l}\text { South } \\
\text { Korea } \\
\end{array}$ & Pakistan & Singapore & $\begin{array}{l}\text { Hong } \\
\text { Kong }\end{array}$ & Norway & Japan & $\begin{array}{c}\text { Nether- } \\
\text { lands }\end{array}$ & India & $\begin{array}{c}\text { Sri } \\
\text { Lanka }\end{array}$ \\
\hline Telecom & 0 & 0 & 0 & 51.2 & 0 & 103.4 & 4.8 & 0 & 0.5 & 0 \\
\hline $\begin{array}{l}\text { Gas \& } \\
\text { Petroleum }\end{array}$ & 0 & 0 & 0 & 0 & 0 & 0 & 0 & 0 & 0 & 0 \\
\hline Power & 0 & 0 & 0.01 & 3.2 & 3.42 & 0 & 4.1 & 12.86 & 0 & 10.5 \\
\hline $\begin{array}{l}\text { Textiles \& } \\
\text { Wearing }\end{array}$ & 39.5 & 99.6 & 0 & 12.16 & 46.41 & 0 & 3.1 & 11.53 & 9.1 & 4.1 \\
\hline Banking & 92.3 & 2.8 & 110.2 & 0 & 26.91 & 0 & 0 & 0 & 16.8 & 43.3 \\
\hline Others & 49.2 & 32.3 & 20.5 & 50.5 & 34.67 & 0.1 & 83.8 & 54.31 & 41.4 & 3.5 \\
\hline Total & 181 & 134.7 & 130.7 & 117.1 & 111.41 & 103.6 & 95.7 & 78.70 & 67.8 & 61.4 \\
\hline
\end{tabular}

Data Source: Bangladesh Bank Statistics

Investigation of top ten investing countries also indicates that the countries are changing over time as well in terms of their ranking. These indicate that Bangladesh definitely has potential in attracting more FDI; however, steps need to be taken to overcome some of the obstacles to FDI. Most importantly, policies should be taken to attract FDI inflows to the power sector which the country desperately needs. 


\section{DATA AND METHODOLOGY}

Data for this study has been obtained from the Bangladesh Bank Statistics, World Bank and UNCTAD data websites. The data is a time series data for the period 1994-2014. To investigate the impact of FDI on economic activities of the country, the dependent variables considered were gross domestic product, employment, exports, imports, and domestic investments in Bangladesh. Because the impact of FDI causes employment in other supportive industries, total employment in the country was considered in this study instead of considering employment in the sectors receiving the FDI. Our choice of independent variables was restricted by data availability. For example, data on average wages, employment in different sectors, and tax rates were not available for Bangladesh for all the years. For the empirical models, data from 1994 to 2014 was collected from the World Bank. To investigate the Kuznet's curve, linear monotonous and N-shaped relationship, we postulate the following models:

To investigate the impact of FDI on GDP the following four empirical models were estimated:

$$
\mathrm{GDP}_{\mathrm{t}}=\mathrm{b}_{0}+\mathrm{b}_{1} \mathrm{FDI}_{\mathrm{t}}+\mathrm{b}_{2} \mathrm{FDI}_{\mathrm{t}}^{2}+\mathrm{b}_{3} \mathrm{FDI}_{\mathrm{t}}{ }^{3}+\mathrm{b}_{4} \mathrm{k}_{\mathrm{t}}+\mathrm{b}_{5} \mathrm{C}_{\mathrm{t}}+\mathrm{b}_{6} \mathrm{NX}_{\mathrm{t}}
$$

To investigate the impact of FDI on exports the following empirical model was estimated:

$$
\mathrm{X}_{\mathrm{t}}=\mathrm{b}_{0}+\mathrm{b}_{1} \mathrm{FDI}_{\mathrm{t}}+\mathrm{b}_{2} \mathrm{FDI}_{\mathrm{t}}^{2}+\mathrm{b}_{3} \mathrm{FDI}_{\mathrm{t}}^{3}+\mathrm{b}_{4} \mathrm{k}_{\mathrm{t}}+\mathrm{b}_{5} \mathrm{Open}_{\mathrm{t}}+\mathrm{b}_{6} \text { XPrice }_{\mathrm{t}}
$$

To investigate the impact of FDI on imports the following empirical model was estimated:

$$
\mathrm{M}_{\mathrm{t}}=\mathrm{b}_{0}+\mathrm{b}_{1} \mathrm{FDI}_{\mathrm{t}}+\mathrm{b}_{2} \mathrm{FDI}_{\mathrm{t}}^{2}+\mathrm{b}_{3} \mathrm{FDI}_{\mathrm{t}}^{3}+\mathrm{b}_{4} \mathrm{k}_{\mathrm{t}}+\mathrm{b}_{5} \text { Open }_{\mathrm{t}}+\mathrm{b}_{6} \text { MPrice }_{\mathrm{t}}
$$

To investigate the impact of FDI on domestic investments the following empirical model was estimated:

$$
\mathrm{K}_{\mathrm{t}}=\mathrm{b}_{0}++\mathrm{b}_{1} \mathrm{FDI}_{\mathrm{t}}+\mathrm{b}_{2} \mathrm{FDI}_{\mathrm{t}}^{2}+\mathrm{b}_{3} \mathrm{FDI}_{\mathrm{t}}^{3}+\mathrm{b}_{4} \mathrm{GDP}_{\mathrm{t}}+\mathrm{b}_{5} \mathrm{Open}_{\mathrm{t}}
$$

Where, $t$ refers to period $t$ and:

$\begin{array}{ll}\text { GDP } & =\text { gross domestic product in millions of } \$ \\ \text { FDI } & =\text { inflow of foreign direct investments in millions of } \$ \\ \text { FDI }^{2} & =\text { square of FDI } \\ \text { FDI }^{3} & =\text { cube of FDI } \\ \mathrm{K} & =\text { annual percentage growth of gross capital formation } \\ \mathrm{C} & =\text { total consumer's expenditures in millions of } \$ \\ \mathrm{NX} & =\text { net exports }=\text { Exports }- \text { imports in millions of } \$ \\ \text { Open } & =((\text { exports }+ \text { imports }) / G D P) * 100 \\ \text { XPrice } & =\text { Export value index }(2000=100) \\ \text { MPrice } & =\text { Import value index }(2000-100) \\ \mathrm{K} & =\text { gross capital formation in millions of } \$\end{array}$

Export and import value indexes were used as proxies for export and import prices (data source: World Bank). We followed Yanikkaya (2003) and Gries (2009) in our trade openness measurement. Trade openness is often taken as a measurement of trade restrictions. For empirical testing of the functional relationship between FDI and the economic variables the models in equations 1-4 above requires us to test the following:

(i) $b_{1}=b_{2}=b_{3}=0$. Implies no relationship between FDI and the dependent variable.

(ii) $b_{1}>0$ and $b_{2}=b_{3}=0$. Implies a monotonic increasing relationship or a linear relationship between FDI and the economic variable.

(iii) $b_{1}<0$ and $b_{2}=b_{3}=0$. A monotonically decreasing relationship between FDI and economic variable.

(iv) $b_{1}>0, b_{2}<0$ and $b_{3}=0$. An inverted-U-shaped relationship, i.e., the Kuznet's curve.

(v) $b_{1}<0, b_{2}>0$ and $b_{3}=0$. A U-shaped relationship, opposite of Kuznet's curve. 
(vi) $b_{1}>0, b_{2}<0$ and $b_{3}>0$. A cubic polynomial or $\mathrm{N}$-shaped figure.

(vii) $b_{1}<0, b_{2}>0$ and $b_{3}<0$. Opposite to the $\mathrm{N}$-shaped curve.

\section{EMPIRICAL RESULTS}

Our estimation provided the following results:

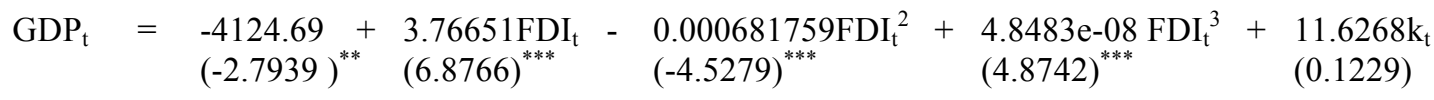

$$
\begin{aligned}
& +\quad 1.30294 \mathrm{C}+0.153148 \mathrm{NX} \\
& \begin{array}{ll}
(35.2679)^{* * *}(1.1282) & \mathbf{R}^{2}=\mathbf{0 . 9 9 9 8}
\end{array}
\end{aligned}
$$

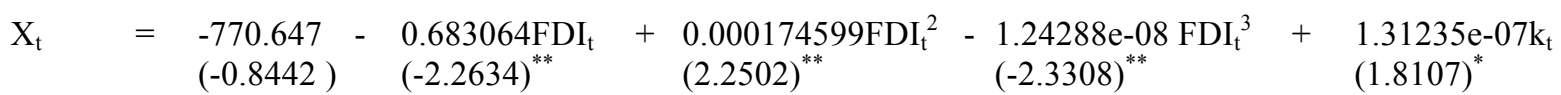

$$
\begin{aligned}
& +\underset{(1.524)}{5025.16 \text { OPEN }}+\underset{(8.73)^{* * *}}{55.3964 \text { XPICE }} \quad \mathbf{R}^{2}=\mathbf{0 . 9 9 9 5}
\end{aligned}
$$

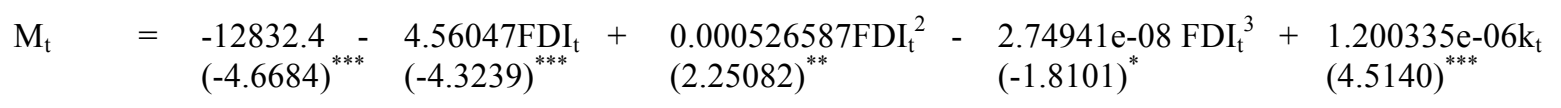

$$
\begin{aligned}
& \begin{array}{rlr}
51894.7 \mathrm{OPEN} & \text { 12.9413MPRICE } \\
(5.4379)^{* * *} & (-0.7471) & \mathbf{R}^{2}=\mathbf{0 . 9 9 7 8}
\end{array}
\end{aligned}
$$

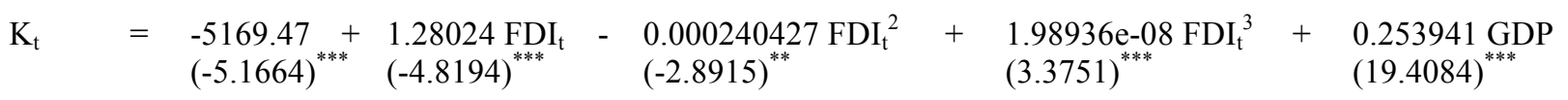

$$
\begin{aligned}
& +\quad \text { 7993.93OPEN } \\
& \begin{array}{ll}
(2.5734)^{* *} & \mathbf{R}^{2}=\mathbf{0 . 9 9 9 5}
\end{array}
\end{aligned}
$$

Note: Numbers in parentheses are the t-statistics, and $* * *, * *$, and $*$ denote significance at $0.01,0.05$, and 0.10 levels respectively.

Given the statistically significant coefficients of FDI, $\mathrm{FDI}^{2}$ and $\mathrm{FDI}^{3}$ it can be inferred from the signs that an $\mathrm{N}$ shaped relationship holds for GDP and total capital formation whereas an inverted-N relationship is confirmed for Exports and Imports. These results clearly indicate that in the earlier stage FDI has a positive impact on GDP and capital formation in Bangladesh followed by a declining period and then showing a positive impact at later stages with high FDI inflow. For exports and imports the relationship is just the opposite. In the earlier stages and for high FDI inflows the relationship is negative while in between there is a positive impact of FDI on the two economic variables. These findings suggest that there is no unique relationship between FDI and economic growth variables; rather the relationship will depend on the timing of observation or more accurately the level of FDI inflow. A portion of the curve for all four of the variables does display either Kuznet's or inverted-U shaped relationship. This further emphasizes the timing of observation: for GDP and capital formation, at earlier stages of FDI inflow one would observe an inverted U-shaped curve while for exports and imports one would observe a U-shaped relationship. On the other hand, at higher levels of FDI inflow just the opposite holds for the variables. The results further suggest there will be turning points in the relationships.

Our empirical findings on relationships have major policy implications: The empirical analysis shows that encouraging high levels of FDI inflows into the country will have a positive impact on the growth of GDP and capital formation of the country. The inverted N-shaped relationship findings in case of imports, indicates that the country can also improve the trade balance with high FDI by lowering imports. For the case of exports, however, 
our study indicates that there could be a downturn of exports for high volumes of FDI. Diversifying exports could be a solution to the problem, since major source of export earnings have been from readymade garments (RMG) in recent years. The percentage of RMG to total exports has grown from $64.17 \%$ in 1994 to $81.68 \%$ for the period of our study ${ }^{2}$ (BGMEA: Bangladesh Garments and Manufacturers and Exporters Association reports). Government could encourage foreign investments in pharmaceuticals and chemicals and also leather and leather products to achieve this goal. Our analysis indicates that taking policies to encourage FDI has positive impact on the growth of the economy with the exception of exports. The negative impact on exports due to high FDI inflow could be counteracted by diversifying the export industries in the country. Furthermore, these N-shaped and inverted Nshaped results indicate that the relationship of the FDI and the economic growth variables will depend on the period of observation. Depending on the period we may observe positive or negative impact of FDI on the economic variables.

\section{CONCLUSION}

Our study contributes to existing studies by not assuming a linear relationship between FDI and the growth variables for the case of Bangladesh, but rather by investigating the true functional relationships for the case of Bangladesh. Future studies in this area could extend the literature by investigating the impact of FDI in the energy and environmental sectors. Sectoral shifts in recent areas also may be an area for research to see which particular policies or changes in markets led to the shifts.

Despite the lack of infrastructure, government bureaucracy, corruption, and most importantly political unrest, Bangladesh still has a few advantages in attracting FDI into the country, such as geographic location, consumer market, and low labor costs. In addition, on the policy side, there are tax exemptions, duty free imports and full repatriation of profits and invested capital.

The findings in this paper indicate that Bangladesh can certainly achieve higher growth and also has the potential in attracting more FDI; however, steps need to be taken to overcome the obstacles of infrastructure, corruption, bureaucracy and red tapes in the government offices. Most importantly, policies should be directed to attract FDI inflows into diverse sectors without compromising the environmental guidelines.

\section{AUTHOR BIOGRAPHY}

Sonia H. Manzoor is the McClure-Whitmarsh-Endowed Associate Professor in Economics at Westminster College, Fulton, MO, USA. She received her Ph.D. in Economics from Texas A\&M University and previously taught at Shenandoah University, University of Kansas, University of Missouri - Kansas City, and William Jewel College. sonia.manzoor@westminster-mo.edu

Manzoor Chowdhury is an Associate Professor of Business \& Economics at Lincoln University. He received his Ph.D. in Applied Economics from Texas A\&M University and had worked in the private sector (Sprint-Nextel, AOL-Time Warner) for over 10 years before coming to the Academia.

chowdhurym@lincolnu.edu

\section{REFERENCES}

Adhikary, K. (2011) "FDI, Trade Openness, Capital Formation, and Economic Growth in Bangladesh: A Linkage Analysis" International Journal of Business and Management, 6: 16-28.

Agosin, M. R. and Mayer, R. (2000) "Foreign Investment in Developing Countries: Does It Crowd In Domestic Investment?" UNCTAD Discussion Paper, 146, Geneva.

Ali, S, Md., Rukunujjaman and Alam, K.J. (2015) "An Empirical Analysis of Foreign Direct Investment and Economic Growth in Bangladesh" International Journal of Business and Economics Research, 4(1): 1-10

Azam, Muhammad (2010) "An Empirical Analysis of the Impacts of Exports and Foreign Direct Investment on Economic Growth in South Asia" Interdisciplinary Journal of Contemporary Research Business, 2 (7): 249-58.

Anu, Muhammed (2015), "Burden of Development” Daily Star Newspaper Bangladesh, February 27, 2014

2 A detailed data of exports of RMG can be found in http://www.bgmea.com.bd/home/pages/TradeInformation 
Balamurali, N. and Bogahawatte, C. (2004) "Foreign Direct Investment and Economic Growth in Sri Lanka" Sri Lankan Journal of Agricultural Economics, 6: 37-50.

Balasubramanyam, V.N., Salisu, M., and Sapsford, D.(1996) "Foreign Direct Investments and Growth in EP and IS countries" The Economic Journal (106): 92-105.

Cole, M. (2004) "Trade, the pollution haven hypothesis and the environmental Kuznets curve: examining the linkages" Ecological Economics, (48): 71-81.

Faruk, M. O. (2013) "The Effect of FDI to Accelerate the Economic Growth of Bangladesh and Some Problems \& Prospects of FDI" Asian Business Review, 2: 37-43.

Hossain, M. A. (2008) "Impact of Foreign Direct Investment on Bangladesh's Balance of Payments: Some Policy Implications" PN 0805, Bangladesh Bank Publications

Islam, A.K.M. (2014) "Foreign Direct Investment (FDI) in Bangladesh: Prospects and Challenges and Its Impact on Economy" Asian Business Review, 4: 24-36.

Khan, Md., A. Islam and Nasir, Fuad B. (2014) "A Review Over Major Gas Blowouts In Bangladesh, Their Effects And The Measures To Prevent Them In Future" International Journal of Scientific and Technology Research, 3(9): 109-113

Kumar, N. and Pradhan, J.P. (2002) "Foreign Direct Investment, Externalities and Economic Growth in developing Countries: Some Empirical Explorations and Implications for WTO Negotiations on Investment” RIS Discussion Papers 27/2002, New Delhi.

Kuznets S. (1955) "Economic Growth and Income Inequality" The American Economic Review, 45: 1-28.

Lee J. W., G.S. Baimukhamedova and Akhmetova, S. (2009) "The Effects of Foreign Direct Investment on Economic Growth of A Developing Country: From Kazakhstan" Allied Academies International Conference. Academy for Economics and Economic Education, 12: 22-27.

Luzzati T, Orsini M. (2009) "Investigating the Energy-Environmental Kuznets Curve" The Energy Journal, 34: 291-300

Markusen, J. R. \& Venables, A. J. (1997) "Foreign Direct Investment as a Catalyst for Industrial Development", NBER Working Papers 6241, National Bureau of Economic Research, Inc.

Mottaleb, K.A. (2007) "Determinants of Foreign Direct Investment and Its Impact on Economic Growth in Developing Countries" MPRA Paper 9457, University Library of Munich.

Musila, J.W., and Sigue, P.S. (2006) "Accelerating Foreign Direct Investment Flow to Africa: From Policy Statements to Successful Strategies" Manegerial Finance, 32: 577-593.

Quader, S. M. (2009) "Foreign Direct Investment in Bangladesh: An Empirical Analysis on its Determinants and Impacts" Retrieved from http://mpra.ub.uni-muenchen.de/26134/MPRA Paper No.26134.

Rahman, A. (2012) “Foreign Direct Investment in Bangladesh, Prospects and Challenges, and its Impact on Economy” Master's Thesis, Asian Institute of Technology School of Management Thailand.

Rehman A. and Orangzab, R. A. (2011) "Determinants of Foreign Direct investment and its impact on GDP Growth in Pakistan" Interdisciplinary Journal of Contemporary Research in Business, 2: 198-205.

Richmond A.K., Kaufman R.K. (2006) "Energy prices and turning points: the relationship between income and energy use/carbon emissions" The Energy Journal, 27: 157-180

Rothgeb, John M., Jr. (1984) “The Effects of Foreign Investment On Overall And Sectoral Growth In Third World States”, Journal of Peace Research, 21(1): 5-15.

Saqib, N., Masnoon, M and Rafique, N. (2013) "Impact of Foreign Direct Investment on Economic Growth of Pakistan" Advances in Management \& Applied Economics, 3(1): 35-45 


\section{NOTES}

